\title{
INNOVATIVE JUDICIAL PROCEDURES AND REDEFINITION OF THE INSTITUTIONAL ROLE OF THE ARGENTINE SUPREME COURT
}

\author{
Alba Ruibal \\ European University Institute
}

\begin{abstract}
This article addresses the way in which the Argentine Supreme Court has set out to redefine its own institutional role through its procedures and decisions, since its institutional reform in 2003. It shows that the Court has developed innovative ways of judicial intervention in public policy and rights issues, which include the participation of new kinds of actors and entail an emerging new relationship between the Court and civil society organizations in Argentina. The article argues that this change can be understood as a way for the Court to rebuild its institutional legitimacy, and that the reform is connected to the presence of strong nongovernmental organizations whose claims for a change in the Court's composition and procedures gained momentum in the aftermath of the social and political crisis of 2001-2002 in Argentina.
\end{abstract}

The Argentine Supreme Court has been analyzed by judicial politics studies that have repeatedly portrayed its behavior as dependent on political competition (Chavez 2004; Helmke 2003; Scribner 2004; Iaryczower, Spiller, and Tommasi 2002). ${ }^{1}$ In this framework, the most significant changes in the Court's actions are determined by either of the two main indicators of party competition-the presence of unified or divided government, or the existence of uncertainty regarding electoral results-which affect the relative power of the executive and, in turn, its capacity to influence the Court. These studies have focused on the Court's independence and have addressed, among other periods, the work of the Court during the 1990s, a time in which its deference to the party in power led to its depiction as one of the most dependent courts in Latin America (Helmke 2003), and a time in which many of its decisions entailed flagrant violations of contract rights and the Constitution (Acuña 2002; Gargarella 2002).

However, after a legitimacy crisis that placed the Court at the center of popular protests during the social and political crisis of 2001-2002 in Argentina, the Court was reformed, and a new period started (see Brinks 2005). By looking at how it set out to develop its work after this reform, this article argues that it is pos-

I am grateful to Matilde J. Farren, Héctor Fix-Fierro, Daniel Brinks, Juan G. Bertomeu, and Jonathan Miller for their comments and help. I also thank the National Autonomous University of Mexico (UNAM), and in particular the Institute of Legal Research, for the opportunity to carry out this work.

1. An exception is the work by Brinks (2005), who addresses the reform of the Court in 2003 and the consequences of new mechanisms for appointing judges on the Court's behavior. The author claims that this reform had a positive impact on the Court's independence.

Latin American Research Review, Vol. 47, No. 3. (c) 2012 by the Latin American Studies Association. 
sible to have both a different picture of and an additional rationale for the Court's behavior. It shows that after the process of Supreme Court reform and renewal initiated in Argentina in 2003, the Court has actively intervened in public policy and rights issues and that in some emblematic cases it has done so through procedures that are innovative in the Argentine context. This article focuses not on the Court's autonomy but on the redefinition of its institutional role and on its new approaches to decision making, and it argues that these developments cannot be fully understood under the political competition rationale but can be attributed to the Court's need to recover its institutional legitimacy in a context marked by the presence of active nongovernmental organizations (NGOs) that had pushed for reforms and, later on, influenced the Court's agenda and procedures in the aftermath of the crisis.

A new relationship between the Court and civil society started just after the Court's renewal in 2003, when it implemented a series of reforms to its own internal procedures that a group of NGOs had proposed with the explicit aim of increasing the Court's legitimacy. These institutional reforms fostered public participation and accountability in the Court's decision making and created new opportunities for strategic litigation and intervention in its procedures by civil society organizations. Afterward, some of those NGOs presented rights claims in cases that the Court upheld and that implied a new approach to judicial decisions. These cases involved violations of collective and individual rights that were addressed from the perspective of the structural reform of institutions (Puga 2008) and present some of the elements of the so-called experimental approach in public interest litigation. ${ }^{2}$ This is only an emerging trend in Argentina, but it is one that implies an innovation in the country's judicial practices and that the Court and rights advocacy organizations have consciously pursued in recent years.

The interaction between citizens and the Court has taken place mainly around a new understanding of the Court's institutional role in terms of its responsiveness to civil society, its intervention in new types of cases, and the introduction of more accountability and transparency in its procedures. These changes have been possible because new justices joined the Court and replaced judges whose actions, as mentioned herein, were systematically identified with the protection of political actors' interests to the detriment of citizens' rights. Certainly, the policy preferences of the new justices may have also played a fundamental role in recent decisions by the Court, which have differed radically from those of the 1990s. However, beyond justices' preferences for policy outcomes, this article claims that to understand why the Court engaged in an unprecedented relationship with actors in civil society and why it implemented innovative decision-making approaches, it is necessary to look at the incentives that emerged from the particular context that preceded the Court's reform. The argument here is that judges developed this type of intervention because they were concerned about the institutional standing and legitimacy of the Court, after a crisis of credibility that made it a focal point of social outburst during the country's political breakdown in 2001-2002. This explanation is in consonance with strategic accounts of judicial

2. I am thankful to Daniel Brinks for this observation. 


\section{Latin American Research Review}

behavior (notably, Epstein and Knight 1998) that affirm that one of the main concerns of judges is maintaining the legitimacy of courts. Legitimacy is understood here as the institutional power of courts, which is associated with so-called diffuse support from the public and is based on the recognition of courts as meaningful and respected actors in their political systems. ${ }^{3}$ The search for legitimacy, and its consequences for assumptions about justices' behavior, can be considered an even more pressing endeavor for new or recently reformed courts that need to build their reputation and enforcement power from scratch or in the aftermath of serious institutional crises, as happened in Argentina.

The first section of this article presents a brief account of the Court's reform process, with an emphasis on the new institutional procedures that were proposed by NGOs and implemented by the Court. The second section addresses decisions and procedures of the Court that indicate a redefinition of its institutional role. The focus is not so much on the Court's jurisprudence, which is nonetheless mentioned, but on new approaches to judicial decision making. The third section shows how the interaction between the Court and NGOs, in the aftermath of a legitimacy crisis, contributes to understanding this recent development.

\section{THE COURT'S REFORM AND THE DEMAND FOR ACCOUNTABILITY AND TRANSPARENCY IN ITS PROCEDURES}

Scholars of the Argentine Supreme Court before reform decried its loss of institutional standing and authority throughout its institutional history (e.g., Carrió 1996; Miller 1997). Overall, the Court was questioned for not having contributed to the maintenance of the constitutional system of checks and balances, and especially for having consented to the delegation of powers to the executive branch, thus fostering hyper-presidentialism (Nino 1993) and undermining its own role in the protection of rights (Gargarella 1998). Furthermore, the lack of transparency of the Court's internal procedures limited the possibilities of public debate about its decisions and contributed to the lack of social recognition of its institutional role (Carrió 1996; Centro de Estudios Legales y Sociales [CELS] et al. 2003; Miller 1997). These tendencies were aggravated during the 1990s, under the presidency of Carlos Menem. ${ }^{4}$ This decade was characterized by political control over the Court and blatant corruption scandals involving some of its justices (see Acuña 2002; Brinks 2005; Carrió 1996; Miller 1997). Regarding its jurisprudence, it has been observed that the so-called Menemist Court exercised a certain type of activism that was opposed to what is commonly understood as judicial activism in constitutional theory, as it was not oriented toward the protection of "individual rights in conflict with governmental interests, but to the defense of the latter"

3. According to Fallon $(2005,1228)$, the institutional legitimacy of a judicial organ such as a supreme court "resides in public beliefs that it is a generally trustworthy decision maker whose rulings therefore deserve respect and obedience." As the author observes, this type of legitimacy has usually been equated with diffuse support from the public to a court as an institution, in contrast to specific support to a particular court's decisions (see, e.g., Caldeira and Gibson 1992).

4. At the beginning of his government in 1990, Menem appointed a group of justices to the Court popularly called the automatic majority, as they systematically upheld presidential decisions. 
(Carrió 1996, 160). Moreover, Gargarella (1998) argues that the Court in the 1990s not only systematically defended the particular interests of the executive but also developed a solid, conservative jurisprudence, supporting policies that were just opposite to egalitarian political and economic trends. Finally, the illegitimate expansion of the Court's jurisdiction during that decade further contributed to the undermining of its credibility and legitimacy (Carrió 1996; CELS et al. 2003). ${ }^{5}$

By the end of the 1990s the Supreme Court went through the most serious legitimacy crisis in its institutional history (Prillaman 2000; Sabsay 2004). In the context of the political and economic crisis of 2001-2002, social insurrection was unprecedentedly directed at the Court as being co-responsible for the country's breakdown. ${ }^{6}$ In January 2002, in the midst of the crisis, a group of NGOs whose work is related to rights litigation and government accountability gathered to propose solutions to the situation of the Court. ' Under the dictum "A Court for Democracy," these organizations developed a comprehensive program for Supreme Court reform to be implemented by the three branches of government (CELS et al. 2002a, 2002b, 2003). The first of these documents expressed that the main aim of the proposals was to recover the Court's legitimacy (CELS et al. 2002a, 1). With regard to the types of changes that were recommended, a member of one of the organizations explained that "they had to do with the tools that NGOs have always dealt with: disclosure and transparency." ${ }^{\prime 8}$

One set of proposals emphasized the need for new, more transparent, and participative procedures for the removal and designation of new justices, considering that the Court's renewal was necessary given its complete lack of legitimacy (CELS et al. 2002b). These reforms were fully implemented by the executive branch and the Senate during the first months of the government of Néstor Kirchner, who took office in May 2003 as the first democratically elected president after the crisis. ${ }^{9}$ Through the application of the new procedures, which gathered vast public attention (Brinks 2005), four new justices were appointed to replace the most publically denounced members of the Court. ${ }^{10}$ It has been argued that these reforms

5. The Court's jurisdiction was broadened under Menem's government by two means: by reducing the minimum damages for which a party can sue in cases in which the national administration is a party, and by giving jurisdiction to the Court as a third level of appeal in pension law cases. Justice Eugenio Zaffaroni explained that allowing for the Court's jurisdiction in pension law issues was unconstitutional (author interview, Buenos Aires, July 4, 2005).

6. See "Por primera vez, la Corte estuvo en el centro de una protesta social," Clarín, December 30, 2001; “Por paliza, para que se vayan todos," Página/12, October 13, 2002.

7. These organizations were Poder Ciudadano, the Center for Legal and Social Studies, the Institute of Comparative Criminal and Social Studies, the Environment and Natural Resources Foundation, the Association for Civil Rights, and the Union of Consumers.

8. María Julia Pérez Tort, coordinator of the Action for Justice area, Foundation Poder Ciudadano (author interview, Buenos Aires, April 21, 2005).

9. Presidential Decree No. 222/03, of June 19, 2003, established new mechanisms of disclosure and public scrutiny of Supreme Court nominees' professional and ethical backgrounds as well as formal mechanisms for civil society to express its opinions about and objections to the nominees. On July 2, 2003 , the Senate introduced more transparency and public participation in its procedures for confirmation hearings.

10. The new justices are Eugenio Zaffaroni (confirmed by the Senate in October 2003), Carmen Argibay (confirmed in July 2004), Elena Highton (confirmed in June 2004, and the first woman to join the 
have so far contributed to the Court's independence (Brinks 2005) and legitimacy (Litvachky and Zayat 2007).

The other group of proposals referred to the internal functioning of the Court and entailed reforms oriented to "achieve greater transparency in the Court's activity and increase its legitimacy and credibility" (CELS et al. 2003, 2). The proposed changes were to limit the Court's competences and the amount of cases it deals with each year; to prohibit meetings between Court members and only one of the parties involved in a case; to disclose the circulation of case files within the Court; to actively implement public hearings, which were included in the Argentine constitutional system but seldom had been used before the Court's reform; to rapidly publish complete Court decisions; and to publish justices' declarations of their assets, in compliance with the Law of Public Ethics from which they had exempted themselves in 2000. Finally, these proposals pointed to the need for justices to pay income taxes, from which members of the Court had also exempted themselves in 1996.

After its reform, the Court entered into unprecedented relationships with actors in civil society and implemented almost all the reforms that the aforementioned NGOs had proposed. In November 2003, soon after being elected president of the Court, Judge Enrique Petracchi received the members of those NGOs, who presented him with the document about internal reforms of the Court, with which he "complete[ly] agreed and committed himself to gradually implement[ing]."11 Later on, Judge Eugenio Zaffaroni met with these organizations to discuss the same type of proposals, which he also supported. The president of one of those NGOs said, "The fact that Zaffaroni was aware of the proposals presented in 'Una Corte para la democracia I y II' and shared in detail many of the issues discussed in that document is encouraging for the prospects of the reconstruction of the bridges, so many times broken, between civil society and the Court."12

At the end of December 2003, the Court set out to implement the proposed reforms through a series of internal agreements (acordadas) that increased transparency and accountability in its own procedures. ${ }^{13}$ In particular, it established the disclosure of the circulation of case files among the different Court justices, ${ }^{14}$ different treatment for cases of institutional significance, including the need to fix the date on which the Court would consider them, ${ }^{15}$ and the full-text publication of the Court's significant decisions. ${ }^{16}$ The Court also stipulated that any meeting between litigants and justices must take place in the presence of the other party as well. ${ }^{17}$ In addition, the Court promoted the participation of civil society in its decision-

Court under a democratic government), and Ricardo Lorenzetti (confirmed in December 2004 and elected chief justice in November 2006).

11. Environment and Natural Resources Foundation (Fundación Ambiente y Recursos Naturales), Boletín Informativo No. 15, December 2, 2003, http://www.farn.org.ar/docs/boletin/boletin015.html.

12. Mario Rejtman, in Infocívica, Poder Ciudadano, June 5, 2003, http://www.infocivica.org.ar.

13. The complete text of these agreements can be found at the website Corte Suprema de Justicia de la Nación, at http://www.csjn.gov.ar/docus/documentos/cons_tipo.jsp?tipo=AC (accessed June 27, 2012).

14. Acordada 35/2003, December 11.

15. Acordada 36/2003, December 18.

16. Acordada 37/2003, December 18.

17. Acordada 7/2004, February 24. 
making processes, mainly by regulating public hearings ${ }^{18}$ and amicus curiae submissions..$^{19}$ In 2006 the Court established that all cases that allow the presentation of amicus briefs would be published on the Court's web page. ${ }^{20}$ The Court also ruled that its members should disclose their assets. ${ }^{21}$ The only recommendation that the Court has not complied with so far is the payment of income taxes. ${ }^{22}$ Finally, as described in the following section, through decisions in particular cases, the Court reduced its scope of competences in order to adjust them to its constitutional role.

\section{INNOVATION IN JUDICIAL POLICY MAKING AND THE NEW INSTITUTIONAL ROLE OF THE SUPREME COURT}

After the mentioned institutional reforms, the Court itself has redefined its own institutional role through new decision-making procedures; through limiting its competences; and through its intervention, for the first time, in structural reform cases. In effect, the Court's decisions on rights and public policy issues not only have brought about a change with respect to the Court's jurisprudence during the 1990s, but in some of these cases, the Court has also implemented new methods of judicial enforcement that have started to redefine its approach to decision making and its relationship with civil society. In addition, in many instances the Court has set an agenda that the other powers of government (i.e., executive and legislative) had not advanced, and it has pushed other powers to act to comply with constitutional rights and guarantees.

As part of this movement toward a new standing in the political system, the Court also created three new areas within its institutional structure that are not directly related to its case law decisions but are worth mentioning because they imply a new conception of its role as well as of its relationships with society. In 2008 and 2009, respectively, the Court established the Office of Domestic Violence, which aims to facilitate access of victims of violence to the judicial system, and the Women's Office, oriented toward introducing a gender perspective into the judiciary. ${ }^{23}$ Also in 2008, it created the Center of Judicial Information, which produces information about the judiciary and publishes it at the Court's website. ${ }^{24}$

18. Acordada 30/2007. Public hearings at the Supreme Court were a mechanism included in the Argentine constitutional system, but they were not formalized and had hardly been used before the Court's reform.

19. Acordada $28 / 2004$, July 14 .

20. Acordada 14/2006, May 3.

21. Acordada 29/2005, December 27.

22. During confirmation hearings the new justices agreed that judges should pay income taxes, and during the Court's renewal, its president Enrique Petracchi said that justices would try to suspend this prerogative ("La Corte busca despegarse del fallo que exime a los jueces de tributar," Página/12, April 19, 2006). However, on April 11, 2006, in a case about a claim by a retired judge of a lower court, a special formation of the Court, of which the majority of its members had excused themselves, decided to maintain this privilege ("Un beneficio controvertido," La Nación, April 12, 2006).

23. The respective websites of these offices are at http://www.csjn.gov.ar/ovd/ovdhome.jsp and http://www.csjn.gov.ar/om/index.html.

24. The website of the center is at http://www.cij.gov.ar/inicio.html. Thury Cornejo (2009) analyzes other communicative strategies developed by the Supreme Court to foster its institutional image and legitimacy. 
New Tendency in the Argentine Court's Jurisprudence on Rights

The main argument of this article is not centered on the Court's doctrine, so only a short reference to salient decisions on rights is presented, ${ }^{25}$ and then emphasis is placed on cases that show a change in the Court's competences and procedures. A thorough assessment of the Supreme Court's activity regarding the enforcement of rights can be found in books and press releases by the Association for Civil Rights (e.g., Asociación por los Derechos Civiles [ADC] 2005, 2006, 2008). In fact, the work produced by that NGO, specifically by its area dedicated to analyze the Supreme Court and bring it closer to the public, ${ }^{26}$ is a relevant aspect of the new dynamics between civil society and the Court in Argentina.

Some of the Court's most important decisions on rights after its reform have reversed the conservative doctrine of the so-called Menemist Court of the 1990s, for example in the area of labor and pension law, ${ }^{27}$ as well as regarding the constitutional guarantees of defendants in criminal processes. ${ }^{28}$ In the area of pension law, the Court issued two main decisions that are particularly important, not only for their content and impact on rights but also for their implications for the Court's institutional role. In 2005, in one of these two decisions (the other is addressed below), the Court declared that its own jurisdiction as an ordinary tribunal of third instance in matters related to pension law was unconstitutional. ${ }^{29}$ At the same time that it corrected an unconstitutional legal reform of the 1990s, this decision contributed to reducing the number of cases that the Court must deal with each year, allowing it to concentrate on matters that are institutionally important (see Litvachky and Zayat 2007). Just one week after this decision by the Court, the Senate repealed the questioned norm. ${ }^{30}$ In the same way, with respect to labor law legislation promulgated in the 1990s, and in particular with regard to on-the-job accident regulations, it was only after the Court's intervention and declaration that those rules were unconstitutional that legislative proposals to change them started to be discussed. ${ }^{31}$

The Court has also decided a series of cases regarding basic social rights and

25. The complete text of the current Supreme Court's decisions, in Spanish only, can be found at the Court's website: http://www.csjn.gov.ar/cfal/fallos/cfal3/cons_fallos.jsp.

26. The website of this area is available at http://www.adc.org.ar/sw_seccion.php?id=127.

27. In 2004, the Court declared unconstitutional a series of regulations implemented during Menem's government that referred mainly to compensation claims and on-the-job accidents and risks (ADC 2005).

28. Legal scholar Roberto Gargarella pointed out that this Court will leave a strong imprint in criminal law and that it has resumed the liberal doctrine of the Court that was developed during President Alfonsín's term (author interview, Buenos Aires, July 5, 2007).

29. Itzcovich, Mabel c/ ANSES s/ reajustes varios, Corte Suprema de Justicia de la Nación (CSJN), file I.349.XXXIX (March 29, 2005).

30. In fact, as Sagües (2005) has pointed out, this was the first time that the Court rejected an attribution assigned to it by the legislative power. The Court acted in this case because of the inaction of Congress, which should have repealed a law that was clearly unconstitutional (Sagües 2005).

31. In this regard, it has been said that "whereas everybody, even businessmen and insurance companies, knew that the system of safety had many shortcuts, only after the Court's decision did a legislative reform start to be discussed with a sense of urgency" ("Cómo hacer que la Corte tenga un peso propio," Página/12, October 17, 2004). 
has compelled the national and provincial governments to act in cases of extreme and urgent need, particularly related to health and food security (see ADC 2006). It has also intervened for the first time in the defense of the rights of aboriginal communities in Argentina, in two main cases that are further addressed below. Among other significant decisions on rights issues, there are two very important cases in which the Court decided clearly against the executive's interest: one of these cases dealt with freedom of the press,,$^{32}$ and the other one was a very salient decision on freedom of union association. ${ }^{33}$

\section{New Ways of Judicial Enforcement and Redefinition of the Institutional Role of the Supreme Court}

Beyond the mentioned changes in the Court's jurisprudence on rights, there has been an even more significant transformation in its decision-making processes in terms of the implications for the Court's institutional role and standing. In several cases, the Court convened public hearings, ${ }^{34}$ and it accepted amicus curiae briefs and the intervention of NGOs as third parties to a case, which allowed for the participation of new types of actors in its decision-making process. In some cases, the Court has developed new criteria about collective rights and individual rights with a collective dimension. Moreover, in two emblematic decisions, it has intervened in structural reform cases, which as Puga (2008) has pointed out, would most certainly have been rejected in the past, and it has implemented for the first time in the Argentine context procedures that can be related to some of the components of the so-called experimental approach in public interest litigation (Sabel and Simon 2004). ${ }^{35}$

In one of its most important decisions in the area of pension law, in 2006, the Court upheld the constitutional guarantee of a mobility criterion to determine increases in the amount of pensions. ${ }^{36}$ It has been noted that initially this decision was

32. In the decision Editorial Río Negro S.A. c/ Neuquén, Provincia del s/ acción de amparo, CSJN, file E.1.XXXIX (September 5, 2007), the Court declared unconstitutional the withdrawal of official advertisements from a newspaper as punishment for an editorial line that is critical of the government.

33. In Asociación Trabajadores del Estado c/ Ministerio de Trabajo s/ Ley de Asociaciones Sindicales, CSJN, file A.201.XL (November 11, 2008) the Court upheld a claim presented by an association of workers regarding the right to be elected as a workers' representative without being affiliated with an officially recognized union. In this way, the Court opened the door to union plurality, which was against the interests of the centralized Confederación General del Trabajo (CGT), a key ally of the national government ("Histórico fallo de la Corte: Aprobó la libertad sindical," La Nación, November 18, 2008).

34. Rolando Gialdino, in charge of the labor law division at the Supreme Court, argues that the type and number of cases in which the Court holds public hearings "depends on the institutional role the Court aims to assume." He also pointed out, in 2005, that the current Court was holding more public hearings than it had held in its whole existence: "It is a new trend, there are three or four hearings per year; they are not many, but there is a tendency to use this mechanism" (author interview, Buenos Aires, April 29, 2005).

35. As explained by Bergallo $(2005,19)$, the remedial model generally applied by Argentine judges when seeking to repair organizational and institutional causes of harm was based on "the 'command and control' style of vertical regulation in which a central authority dictates specific instructions to administrative bureaucracies."

36. Badaro, Adolfo Valentín c/ Anses s/ ajustes varios, CSJN, file B.675.XLI (August 8, 2006). 
against the executive's interests. ${ }^{37}$ What was new about this case is that the Court did not specify the ratio that should be applied for calculation; instead, it ordered the Argentine National Congress to establish a mechanism to increase pensions; moreover, the Court established not a deadline but a criterion for a "reasonable time" for Congress to act to redress the extant unconstitutional situation. Judge Ricardo Lorenzetti explained that this initial decision by the Court in this case was "more appropriate for a dialogue between powers," and he added that the Court would monitor compliance with its decision. He also pointed out that this was "an innovative measure in our system but a very beneficial one for the people," because instead of deciding on an individual case, it obliged Congress to reverse a situation that affected a great number of citizens. ${ }^{38}$ However, Congress acted late, promulgating a law in 2007 that did not comply with the constitutional principle of mobility in the amount of pensions (it established a fixed percentage for all cases). So, the Court decided for the individual case and declared that the new norm was unconstitutional. In 2008, the executive sent a new law to Congress establishing a mobility mechanism, which was approved in October of that year. It has been argued that this law was "a result of successive interventions of the Court and of the dialogical stand that it developed with the political powers through its decisions." ${ }^{\prime 39}$

The Court also intervened for the first time in two cases regarding the appalling living conditions of aboriginal communities in Argentina. In 2007, the national public defender presented a claim against the national government and El Chaco Province for violations of the fundamental rights of Toba communities in that province; eleven persons had died of malnutrition in the two months previous to the claim. ${ }^{40}$ Considering the gravity of the situation, the Court immediately ordered the respective authorities to provide assistance to these communities, and it convoked a public hearing before issuing a decision in which it ordered that in thirty days the respective governments inform the Court about the implementation of health, education, potable water, and infrastructure programs in the communities. After its decision, the Court held new public hearings to supervise the progress of the case. In 2008, the Court upheld a petition by seven indigenous communities and an organization of small producers from Salta Province and ordered the preventive measure of stopping deforestation of aboriginal lands in the province of Salta, which was carried out by big soya entrepreneurs. ${ }^{41}$ In 2009, the Court convoked new public hearings on this case, ${ }^{42}$ and it accepted an amicus brief written by three environmental organizations. ${ }^{43}$

37. Álvaro Herrero, director of the justice area of the Association for Civil Rights, in "La Corte juega fuerte," La Nación, December 15, 2008.

38. "Es urgente, hay un derecho violado," Página/12, August 10, 2006.

39. This evaluation was stated in the amicus curiae brief presented by legal scholars before the Supreme Court of Buenos Aires, which is mentioned later here.

40. Defensor del Pueblo de la Nación c/ Estado Nacional y otra (Provincia del Chaco) s/ proceso de conocimiento, CSJN, file D.587.XLIII (September 18, 2007).

41. Salas, Dino y otros c/ Salta, Provincia de y Estado Nacional s/ amparo, CSJN, file S.1144.XLIV (December 29, 2008).

42. "Cruce de igual a igual por los desmontes," Página/12, February 19, 2009.

43. The organizations are Fundación Ambiente y Recursos Naturales, Greenpeace, and Fundación Vida Silvestre Argentina. The complete text of this brief can be found at the website of the Fundación 
In addition, in a series of cases the Court has developed new criteria about collective cases in which there exists a violation of individual rights that affects a group of persons homogeneously. ${ }^{44}$ This has allowed for the intervention of the Court in cases such as a claim presented in 2006 by a group of physicians and two professional associations regarding the infrastructure, equipment, and basic conditions for functioning of a public hospital in Salta Province. ${ }^{45}$ In this case the Court considered that the precarious situation of that hospital was enough to merit the Court's intervention in the case, and it indicated the provincial high court must rectify its previous decision in which it had declared itself incompetent to attend the case. ${ }^{46}$

Finally, in two cases referring to imprisonment conditions and environmental damages, the Court upheld collective petitions and intervened in structural reform or complex litigation, respectively. These cases are related to structural violations of rights, whose solution cannot be addressed on an individual basis but require a collective remedy (Courtis 2005). This approach indicates the beginning of a new relationship among the Court, political power and bureaucratic agencies, and civil society. It also entails a new way of protecting and enforcing rights in Argentina.

In May 2005, the Court upheld a collective proceeding on habeas corpus presented by the Center for Legal and Social Studies (CELS) on imprisonment conditions in the province of Buenos Aires ${ }^{47}$ In its decision, the Court ordered the three provincial branches of government to review the legal status and the detention conditions of the more than thirty thousand persons under arrest, to adapt them to constitutional and international norms. This case is emblematic in terms of the implementation of innovative judicial procedures. In the first place, the Court upheld for the first time a collective habeas corpus brief, which was possible because the constitutional reform of 1994 conferred legal standing to NGOs as plaintiffs in amparo (emergency judicial relief) and habeas corpus briefs and allowed for the use of these remedies to defend rights that have a collective dimension. Second, several public hearings were held on this case, and for the first time the Court accepted amicus curiae briefs, which several organizations submitted..$^{48}$ Third, in this case the Court introduced two innovations to the enforcement of public policies, as well as in its own role in their implementation, which are related to experi-

Ambiente y Recursos Naturales, at http://www.farn.org.ar/prensa/gacetillas2009/amicus_salta300709 .html.

44. A definition by the Supreme Court of this type of case can be found in Halabi, Ernesto c/ P.E.N. Ley 25.873 Dto. 1563/04 s/ amparo ley 16.986, CSJN, file H.270.XLII (February 24, 2009).

45. Ministerio de Salud y/o Gobernación s/ acción de amparo, CSJN, file M.291.XL (October 31, 2006).

46. Other important collective cases upheld by the Court are Monner Sans, Ricardo c/ Fuerza Aérea Argentina s/ amparo Ley 16.986, CSJN, file M.2975.XXXVIII (September 6, 2006); Asociación Civil Mujeres por la Vida, CSJN, file M.970.XXXIX (October 31, 2006); and Defensoría del Pueblo de la Ciudad de Buenos Aires c/ Secretaría de Comunicaciones, CSJN, file D.859.XXXVI (October 31, 2006).

47. Verbitsky, Horacio s/ habeas corpus, CSJN, file V.856.XXXVIII (May 3, 2005).

48. The organizations that intervened in this case were the Comisión Nacional de Juristas, Asociación por los Derechos Civiles, Clínica Jurídica de Interés Público de Córdoba, El Ágora, Casa del Liberado, Centro de Comunicación Popular y Asesoramiento Legal, Human Rights Watch, and Organización Mundial contra la Tortura. 


\section{Latin American Research Review}

mentalism. On the one hand, the Court's decision did not impose the measures that other powers should implement, but it established parameters to evaluate the improvement in the situation and indicated the obligation of the different powers to act in order to comply with them. Moreover, it established that a permanent discussion panel be formed between the provincial authorities and civil society organizations, to define courses of action and to supervise the development of this case. On the other hand, the Court assumed for the first time a continuing controlling and monitoring role of its decision, by requiring that the monitoring board present a report every sixty days and that the government of Buenos Aires present, also every sixty days, a report on the measures it had adopted to improve the situation of detainees.

As a consequence of the Court's intervention in this case, there was a significant reduction in the imprisonment rate in the province of Buenos Aires; previously, the rate had been one of the highest in Latin America, surpassed only by Chile (Borda and Pol 2007). As a result of this decision, in 2006 the legislature of the province of Buenos Aires reformed the incarceration rules according to the Court's requirements; moreover, courts in other provinces had changed their jurisprudence, and the judicial power had made changes to its practices as well. ${ }^{4}$ However, according to CELS, until 2007 there was progress being made in this case, but since governor Daniel Scioli took office, overpopulation and conditions in jails have worsened. ${ }^{50}$ In attending CELS's claim, in February 2010 the Court required the Supreme Court of Buenos Aires to intervene in the case. In August 2010 a group of legal scholars presented an amicus curiae brief to the Buenos Aires provincial court. ${ }^{51}$ In alluding to the difficulties in implementing remedies in this case, a member of CELS explained, "If this case is considered as one more case of litigation, it can be argued that the Court's decision has not been fulfilled; but in structural litigation we are dealing with a process that depends on the relative power and the relationship between different actors and institutions, and the Court's intervention is a point of departure, and a long time is needed to evaluate if it has been successful." 52

In a case regarding pollution of the basin of the Matanza-Riachuelo River in the city of Buenos Aires and Greater Buenos Aires, in 2006 the Court upheld a claim presented by residents of that area in which they denounced severe environmental damages caused by the numerous industries located along the river, as well as by other pollution sources, which had been allowed by the inaction of the three governmental levels with jurisdiction over that area. ${ }^{53}$ The Court considered

49. Rodrigo Borda, lawyer in the program Institutional Violence and Citizens' Security, CELS (author interview, Buenos Aires, June 20, 2007).

50. "Tienen condiciones inhumanas," Página/12, March 10, 2010.

51. The complete text of this brief can be found at the website of the Universidad de Palermo, at http://www.palermo.edu/Archivos_content/derecho/pdf/Amicus-Curae.pdf.

52. Paula Litvachky, director of the area Democratic Justice, CELS (author interview, Buenos Aires, June 15, 2007).

53. The claim was against the national, provincial, and municipal governments as well as against forty-four businesses. 
the right to a safe environment to be a collective right; it accepted the participation as third parties of several organizations whose institutional goals were related to environmental issues, ${ }^{54}$ and it held several public hearings with governmental authorities, businesses, and NGOs. As in the formerly alluded-to case, in this case the Court did not establish the policies that should be implemented but indicated that the three governmental levels involved, as well as the manufacturers, should reach an agreement on a long-term plan to improve the situation. In 2006, in response to the Court's intervention, the national government promoted the creation of an institutional structure (the Interjurisdictional Basin Authority), which was established by federal law..$^{55}$ Also in that year, the National Secretary of Environment presented a plan to remedy the situation, and the Court mandated the intervention of the University of Buenos Aires to evaluate the plan's viability. ${ }^{56}$ In several public hearings, the Court severely questioned the national government's lack of action in this case, ${ }^{57}$ and after a long process it issued a verdict. ${ }^{58}$ Since then it has continued holding public hearings to control the development of governmental policies and business activities in this area.

The cases presented here have important implications for the redefinition of the Court's institutional role and standing. To begin with, in the two latter cases, the Court accepted new types of claims and claimants, that is, complex litigation through collective proceedings. ${ }^{59}$ In addition, in several rights-based cases, the Court started to implement new procedures established or formalized through recent reforms to its internal procedures. In particular, it promoted public hearings and the reception of amicus curiae briefs, which allow for the participation of new types of actors in the Court's decision-making processes. The Court has also introduced innovative procedural forms. In effect, in several of these cases, it did not establish the policies that other powers should implement but opened a process of dialogue among different types of actors. It set standards, parameters, and time limits that other powers should comply with, and it mandated the adaptation of legislation or the formulation of programs. Instead of closing the cases with a conclusive decision, the Court initiated a long-term process for the implementation of policies that should be defined by the diverse actors involved. In this sense, it has been remarked that in some cases the Court has not established

54. This legal resource is established by article 90 of the National Civil and Commercial Procedural Code (Código Procesal Civil y Comercial de la Nación). The organizations that intervened in this case were Fundación Ambiente y Recursos Naturales, Fundación Greenpeace Argentina, Fundación Metropolitana, Fundación Ciudad, Poder Ciudadano, Centro de Estudios Legales y Sociales, and Asociación Vecinos de La Boca.

55. Law No. 26,168 (Ley de la Cuenca Matanza Riachuelo) was promulgated by the National Congress on November 15, 2006.

56. “Cuenca Matanza Riachuelo: Plan presentado por las autoridades estatales-Factibilidad; Intervención de la Universidad de Buenos Aires," LexisNexis Argentina, February 23, 2007.

57. "El plan de saneamiento del Riachuelo ante la Corte," Página/12, July 5, 2007.

58. Mendoza, Beatriz S. y otros c/ Estado Nacional, Provincia de Buenos Aires y ciudad autónoma de Buenos Aires s/ daños y perjuicios, CSJN, file M.1569.XL (July 8, 2008).

59. In this sense, Juan González Bertomeu, member of the area Poder Judicial-Corte Suprema, ADC, observed, "Never before would the Argentine Court have accepted a structural litigation claim" (author interview, Buenos Aires, June 8, 2007). 


\section{Latin American Research Review}

"direct solutions, but rather experimental remedies, in search of agreement between the parties." ${ }^{\prime 60}$

Through these decisions the Court has intervened in significant institutional issues and has established relations and obligations among different powers. In particular, it has forced the national Congress to promulgate or repeal legislation about pension and labor rights, and it has mandated the legislature of the province of Buenos Aires to modify its legislation on imprisonment conditions. It has also ordered the other levels of the judicial power to change their jurisprudence and practices, in particular regarding rights in criminal processes and incarceration conditions. Furthermore, the Court mandated that the national executive power create an institutional structure (the Interjurisdictional Basin Authority) and develop a long-term governmental plan to solve environmental problems in cases of river contamination.

This type of approach entails a new standing of the Court and has implications in terms of deliberative practices and democratic principles. It is an example of the way in which a judicial organ may intervene in public policy and the enforcement of social rights without imposing a definite course of political action on democratically elected powers. Legal scholar Roberto Gargarella has observed that this Court has a "more procedural vision, a dialogic style of non-imposition, promoted by some of its justices," and he added that, whereas "in substantive terms this Court is different from the former one [composed by a Menemist majority], in procedural terms it is also different from the Court under Alfonsín's government." ${ }^{\prime 61}$ Its role in these cases contributes to keeping the Court away from countermajoritarian objections, and in this way it may also foster its own legitimacy. For example, regarding the Court's decision on imprisonment conditions, a member of the main NGO that intervened in the case observed that the approach developed by the Court "was one of the reasons why this decision didn't generate adverse reactions." ${ }^{\prime \prime 2}$ In this regard, Justice Eugenio Zaffaroni argued that this Court "has been very prudent and careful, because it hasn't told the other powers the concrete solution to be adopted, acknowledging in this way the space of political discussion and decision that is inherent to other powers. With extreme care, the Court has limited itself to indicate that a response to certain problems couldn't be ignored or omitted." ${ }^{\prime 63}$

The fact that the Court has adopted an active and continuing monitoring role with respect to the other powers' action in cases of structural litigation implies an innovative accountability mechanism in Argentina and a new standing of the

60. Juan González Bertomeu, member of the area Poder Judicial-Corte Suprema, ADC (author interview, Buenos Aires, June 8, 2007).

61. Roberto Gargarella, legal scholar (author interview, Buenos Aires, July 5, 2007).

62. Rodrigo Borda, lawyer in the program Institutional Violence and Citizens' Security, CELS (author interview, Buenos Aires, June 20, 2007).

63. “La Corte juega fuerte," La Nación, December 15, 2008. In the same sense, legal scholar Ricardo Gil Lavedra expressed that "the Court is taking the first steps in the formulation of new institutional relations between powers. This is a kind of 'dialogue' that favors deliberation and preserves democratic mandates. So far, the Court has acted with prudence and moderation but has shown its determination and that it is willing to assume an active role in the protection of rights" ("Un nuevo actor en escena," La Nación, December 15, 2008). 
Court with regard to the protection of constitutional rights and guarantees. It is an incipient tendency but a significant one in the history of the Court. Finally, as Puga (2008) has noted, beyond the auspicious perspectives opened by the intervention of the Court in structural cases and given the complexity of these cases, one of the main questions that remains open is whether an agreement will finally be reached among the different actors involved to redress the situations in which these violations of rights originate.

\section{INTERACTION BETWEEN THE SUPREME COURT AND CIVIL SOCIETY IN THE REDEFINITION OF THE COURT'S INSTITUTIONAL ROLE}

The rationales that explain judicial behavior based on divided government or electoral uncertainty are not sufficient for understanding the Court's actions since its reform in 2003. On the one hand, government was not divided during this period: from the first months of Kirchner's presidency, the government had legislative support in both chambers, ${ }^{64}$ strengthened its support base in Congress in the midterm elections of 2005 (Calvo 2005), and won first-round presidential elections in 2007. In addition, there was no real electoral uncertainty, as polls indicated that the government had a strong probability of winning elections in 2007.65 On the other hand, it would be hard to argue that the Court acted in the way it did because of its dependence on a strong executive. In this regard, it has been remarked that the new justices were not identified with any political faction or interest group close to the government, ${ }^{66}$ and that this was "an independent and technically competent Supreme Court as we have seldom had in our history." ${ }^{167}$ It has also been pointed out that, even if on many occasions the Court's decisions did not contradict the executive's policy orientation, the decisions have expanded "the public agenda, especially the government's, as no other force either in parliament or in the opposition can do." ${ }^{\prime 68}$ Finally, in some significant cases the Court decided overtly against the executive's interests. ${ }^{69}$ In fact, another type of study would be necessary to systematically analyze the Court's behavior in terms of its

64. Despite the fact that Kirchner was elected with only 22 percent of the vote, as Levitsky and Murillo $(2003,164)$ point out, neither of the several factions into which the Partido Justicialista was divided during the electoral race had a majority in either chamber, and "during the first weeks of Kirchner's government the [Partido Justicialista's] legislative faction reunified and the vast majority of party bosses ... came together behind a new party leadership."

65. “Otras dos encuestas dan a Kirchner y a Cristina arriba," Clarín, March 5, 2007.

66. Hernán Gullco, coordinator of the area Justice and Public Litigation, ADC (author interview, Buenos Aires, April 19, 2005).

67. Roberto Gargarella, “Corte: Polémica justificación para decisiones clave," Clarín, July 30, 2007.

68. "El tren bala institucional," Página/12, October 17, 2004.

69. Besides the two important cases on the rights of freedom of the press and liberty of union association, in a 2004 case that was pivotal to the government's interests, the Court ruled against the government, deciding that the reform the constitution of Santiago del Estero, which was the main goal of federal intervention in that province, was unconstitutional (see Brinks 2005). In two cases from 2007 and 2008, respectively, the Court upheld the right of two former high officials accused of human rights violations during the previous dictatorship to assume office as elected deputies; it has been claimed that in these cases the Court reaffirmed its independence with respect to the national government (ADC 2008). 
independence. However, it can be asserted that the Court has not been accused so far of being subservient to political power or to other types of actors. So, the explanations based on party competition do not seem to adequately explain why in this context the Court assumed a new role in public policy and rights cases, setting an agenda and compelling other powers to act on issues that the political branches of government were not attending to and issuing some decisions that contradicted the executive's will.

This article argues instead that after a serious institutional crisis, the new Court needed to recompose its institutional legitimacy and that it did so first by introducing new mechanisms to increase public participation and accountabilitywhich, as already mentioned, had been proposed by NGOs-and, later, by developing new ways of decision making that incorporated social actors and created new forms of intervention by the Court in salient public policy and rights cases. This argument is based on contextually configured incentives that made the Court's legitimacy a central concern for justices, as well as for other actors in the political system. This case shows that concerns about the legitimacy of a court may become more salient at certain junctures, and that courts' actions may be influenced by them. As noted earlier, immediately after the Court's renewal, justices were willing to develop new relationships with social actors that were positioned as relevant interlocutors regarding the Court's reform. In effect, influential NGOs in the context of the 2001-2002 crisis found an opportunity to advance a series of proposals for change in the Court that have been upheld and implemented almost in their entirety by the government and the Court since 2003. Subsequently, the work of these organizations contributed to the Court's opening to new procedures, new types of cases, and innovative ways of judicial enforcement, thus influencing the Court's agenda. The Court, again, was willing to uphold judicial claims by social actors and to pursue new strategies of intervention in new types of cases. In this way, new approaches to decision making can be seen as the result of a process that involved citizens' proposals, the Court's institutional changes to its own procedures, citizens' participation in the Court's processes through new institutional mechanisms, and the Court's upholding of new types of cases and implementation of new ways of judicial enforcement.

As has been discussed, NGOs' proposals for the Court's reform were framed as a way to enhance the Court's legitimacy. Significantly, justices themselves have manifested their concern about the need to rebuild the legitimacy of the judiciary and of the Court in particular. When elected as the Court's president in November 2003, Judge Enrique Petracchi remarked that one of the priorities of the Court was "to improve the image of the justice system and the Supreme Court," and he commented that his colleagues shared this aim. ${ }^{70}$ One of his first actions after his election was to meet with those NGOs to discuss institutional reforms for the Court. The Court's vice president since September 2005, Judge Elena Highton, expressed that "judges need to be recognized by society because citizens have to recover 
their trust in institutions." ${ }^{\prime 11}$ In one of his first public statements as the current president of the Court, Judge Ricardo Lorenzetti said, "The judiciary has suffered a crisis of confidence, which must urgently be restored by means of suitable gestures and measures, bearing in mind the delicate institutional role of judges as the guardians of the rights of all citizens."72 Justice Carmen Argibay responded, "This Court is committed to the people. We have worked hard to implement public hearings. ... [W] have intervened in very important cases, such as in the recovery of the Riachuelo, the office for the assistance of victims of domestic violence."73 As part of the new understanding of the role of judges, Justice Eugenio Zaffaroni mentioned that it is important for the people "to know about the debates and positions among judges and to exert as much public control over the judiciary as over any other power." ${ }^{\prime 74}$

In this context, the new types of cases and procedures that the Court has developed have been understood as part of the Court's efforts to establish itself as a legitimate and meaningful actor. Legal scholar Roberto Gargarella explained, "The Court assumes the Riachuelo as an exemplary case, and what is impressive about it is that, without imposing a policy decision, it obligates public officials and industries. They act because they are very concerned about repositioning the Court as a respectable actor." ${ }^{\prime 75}$ Legal scholar and ADC member Juan González Bertomeu pointed out, "This Court needs to re-legitimate its role, and it does so where it can. The challenge is that the Court has to face a strong government, so it chooses cases of public impact"; he added that in structural reform cases, "the Court has much to gain. The Riachuelo case can be the most important case in its history." ${ }^{\prime 76}$ In the same vein, Andrea Pochak, adjunct director of CELS, argued, "The Court's decision about imprisonment conditions in the politically most important Argentine province shows the Court's interest in becoming a significant political actor." ${ }^{\prime 77}$ With regard to the Court's relationship with society in general, it has been claimed that "the current Court has made some efforts to be accessible to people, to communicate more than the previous justices, to be done with enigmas and secrets." 78 Finally, several actors have acknowledged the more dialogic approach of the Court to certain cases as a new positioning of the Court regarding other powers and as part of a new understanding of its mission, which implies neither recusing itself in very sensitive public policy issues that imply gross violations of citizens' rights nor imposing a fixed course of action on democratically elected powers.

71. Presentation of Judge Elena Highton at the First National Conference of Judges, Santa Fe, March 2006, http://www.csjn.gov.ar/documentos/verdoc.jsp (accessed September 2010).

72. Second National Conference of Judges, Salta, August 2007, available at the website of Revista Pensamiento Penal, http://www.pensamientopenal.com.ar/01102007/Lorenzetti.pdf.

73. "Argibay: 'La Corte actúa en muchos temas porque el Estado está ausente,'” Perfil, No. 0323, December 21, 2008.

74. "El fin de la misa en latín y de espaldas," Página/12, June 6, 2010.

75. Author interview, Buenos Aires, July 5, 2007.

76. Author interview, Buenos Aires, June 8, 2007.

77. Author interview, Buenos Aires, June 8, 2005

78. Mario Wainfeld, “Los mensajes y los silencios," Página/12, April 13, 2008. 


\section{Latin American Research Review}

The reform proposals described here, as well as the remarks from academics, NGO members, and justices, show that the main concern regarding the need to redefine the role of the Court was that it be defined not around a certain policy orientation but around a new standing of the Court regarding civil society and the political system in general. The means to change this standing were related to disclosure and accountability and to a new kind of relationship of the Court with other actors and powers. The Court had lost prestige not only for its evident dependence on political power but also because of the opaqueness of its procedures. As part of its institutional reform, the Court modified its internal mechanisms, allowing for more participation and disclosure of its procedures, as NGOs had proposed. After those reforms, the Court, accompanied by NGOs, implemented those mechanisms in concrete cases and through innovative decision making. In this way, the action of the Court after reforms was driven, at least to some extent, by the same dynamics and claims that were relevant at the moment of reform. In particular, the new role of the Court can be attributed to the type of institutional crisis that motivated its reform-which generated incentives for judges to pay special attention to the Court's legitimacy-and to the same type of actors that had pushed for institutional change.

\section{CONCLUSION}

This article has shown that, after its reform in 2003, the Argentine Supreme Court started to redefine its own competences and to adopt an active and innovative role in the implementation of some significant decisions in the field of public policy and rights. The consequences of the Court's decisions for its legitimacy and institutional standing illustrate how the empowerment of courts is related not only to their formal structure and competences but also to their actions and way of functioning.

The Court was aware of the need to redefine its role and gain public recognition, implemented new internal mechanisms oriented toward increasing public participation and accountability in its procedures. Subsequently, it developed new ways of decision making that in some relevant instances incorporated the claims of social actors and upheld the participation of those actors in its decisional processes. The search for institutional legitimacy explains both the creation of new internal mechanisms and the subsequent use of the new procedures by the Court.

The analysis of this case shows that some significant actions and ways of functioning of the Argentine Supreme Court are related to the types of actors and claims that were significant in its reform process. This article does not argue that there exists a causal relationship between both processes but that the way courts build their roles may depend on the same factors that led to their reform in the first place.

Finally, this case suggests that through innovative and more participative procedures, new constitutional courts may start intervening in public policy and rights issues without making themselves vulnerable to countermajoritarian problems. This is a significant issue particularly for courts that have to define their 
roles in contexts signed by profound social inequalities, as in most Latin American cases.

\section{REFERENCES}

Acuña, Carlos

2002 “La dinámica político-institucional de la reforma judicial en la Argentina." Paper presented at the Seventh Centro Latinoamericano de Administración para el Desarrollo International Congress on State Reform and Public Administration, Lisbon, October 8-11.

ADC (Asociación por los Derechos Civiles)

2005 La Corte y los derechos: Un informe sobre el contexto y el impacto de sus decisiones durante el período 2003-2004. Buenos Aires: Asociación por los Derechos Civiles / Siglo Veintiuno.

2006 La Corte y los derechos 2006: Una sintesis de las decisiones más importantes del máximo Tribunal. Buenos Aires: Asociación por los Derechos Civiles.

2008 La Corte y los derechos. Buenos Aires: Siglo Veintiuno.

Bergallo, Paola

2005 "Justice and Experimentalism: Judicial Remedies in Public Law Litigation in Argentina." Seminario en Latinoamérica de Teoría Constitucional y Política. http:// www.law.yale.edu/documents/pdf/Justice_and_Experimentalism.pdf.

Borda, Rodrigo, and Luciana Pol

2007 "Sobrepoblación y hacinamiento carcelario: La instrumentación del fallo 'Verbitsky' y otras estrategias para solucionar el problema." In Derechos humanos en Argentina: Informe 2007, 243-266. Buenos Aires: Centro de Estudios Legales y Sociales / Siglo Veintiuno.

Brinks, Daniel

2005 "Judicial Reform and Independence in Brazil and Argentina: The Beginning of a New Millennium?" Texas International Law Journal 40: 595-622.

Caldeira, Gregory, and James Gibson

1992 "The Etiology of Public Support for the Supreme Court." American Journal of Political Science 36: 635-664.

Calvo, Ernesto

2005 "Argentina, elecciones legislativas 2005: Consolidación institucional del kirchnerismo y territorialización del voto." Revista de Ciencia Política 25 (2): 153-160.

Carrió, Alejandro

1996 La Corte Suprema y su independencia: Un análisis a través de la historia. Buenos Aires: Abeledo-Perrot.

CELS (Centro de Estudios Legales y Sociales), Asociación por los Derechos Civiles, Poder Ciudadano, Fundación Ambiente y Recursos Naturales, Instituto de Estudios Comparados en Ciencias Penales y Sociales, and Unión de Usuarios y Consumidores

2002a "Una Corte para la democracia I." Buenos Aires: Fundación Ambiente y Recursos Naturales. http://www.farn.org.ar/docs/p19.pdf.

2002b "Una Corte para la democracia II." Buenos Aires: Fundación Ambiente y Recursos Naturales. http://www.farn.org.ar/docs/p20.pdf.

2003 "Una Corte para la democracia III." Buenos Aires: Fundación Ambiente y Recursos Naturales. http://www.farn.org.ar/docs/p34.pdf.

Chavez, Rebecca Bill

2004 The Rule of Law in Nascent Democracies: Judicial Politics in Argentina. Stanford, CA: Stanford University Press.

Courtis, Christian

2005 "El caso Verbitsky: ¿Nuevos rumbos en el control judicial de la actividad de los poderes políticos?" In Temas para pensar la crisis: Colapso del sistema carcelario, edited by Centro de Estudios Legales y Sociales, 91-119. Buenos Aires: Centro de Estudios Legales y Sociales / Siglo Veintiuno.

Epstein, Lee, and Jack Knight

1998 The Choices Justices Make. Washington, DC: Congressional Quarterly Press. 


\section{Latin American Research Review}

Fallon, Richard

2005 "Legitimacy and the Constitution." Harvard Law Review 118 (6): 1787-1853.

Gargarella, Roberto

1998 "Después del diluvio: El perfeccionismo conservador en la nueva jurisprudencia de la Corte Suprema (1990-1997)." Desarrollo Económico 38 (149): 439-456.

2002 "Piedras de papel y silencio: La crisis política argentina leída desde su sistema institucional." In Derechos humanos en la Argentina: Informe 2002, 487-498. Buenos Aires: Centro de Estudios Legales y Sociales / Siglo Veintiuno.

Helmke, Gretchen

2003 "Checks and Balances by Other Means: Strategic Defection and Argentina's Supreme Court in the 1990s." Comparative Politics 35 (2): 213-230.

Iaryczower, Matías, Pablo T. Spiller, and Mariano Tommasi

2002 "Judicial Independence in Unstable Environments, Argentina 1935-1998." American Journal of Political Science 16 (4): 699-716.

Levitsky, Steven, and Maria Victoria Murillo

2003 "Argentina Weathers the Storm." Journal of Democracy 14 (4): 152-166.

Litvachky, Paula, and Demián Zayat

2007 "Procesos de cambio en la justicia argentina: Hacia un nuevo modelo de Corte Suprema y el futuro del Consejo de la Magistratura." In Derechos humanos en Argentina, Informe 2007, edited by Centro de Estudios Legales y Sociales, 115-150. Buenos Aires: Siglo Veintiuno.

Miller, Jonathan

1997 "Judicial Review and Constitutional Stability: A Sociology of the US Model and Its Collapse in Argentina." Hastings International and Comparative Law Review 21:

Nino, Carlos 77-176.

1993 "On the Exercise of Judicial Review in Argentina." In Transition to Democracy in Latin America: The Role of the Judiciary, edited by Irwin P. Stotzky, 316-335. Boulder, CO: Westview Press.

Prillaman, William

2000 The Judiciary and Democratic Decay in Latin America: Declining Confidence in the Rule of Law. Westport, CT: Praeger.

Puga, Mariela

2008 "La realización de derechos en casos estructurales: Las causas 'Verbitsky' y 'Mendoza."' Universidad de Palermo, Buenos Aires. http://www.palermo.edu/derecho/ publicaciones/pdfs/Beca_estimulo.pdf.

Sabel, Charles F., and William H. Simon

2004 “Destabilization Rights: How Public Law Litigation Succeeds." Harvard Law Review 117 (4): 1015-1101.

Sabsay, Daniel

2004 "El juicio político a la Corte Suprema en la República Argentina." Anuario Iberoamericano de Justicia Constitucional 8: 493-519.

Sagües, Néstor

2005 "La revisión judicial de la determinación legislativa de la competencia apelada de la Corte Suprema de Justicia de la Nación." LexisNexis Argentina, digital edition, May 6.

Scribner, Druscilla

2004 "Limiting Presidential Power: Strategic Decision-Making on the Supreme Court in Chile and Argentina." Paper presented at the Annual Meeting of the Southern Political Science Association, New Orleans (January).

Thury Cornejo, Valentín

2009 "Representaciones mediáticas y legitimidad judicial: Un estudio de caso sobre la Corte Suprema de la República Argentina." Paper presented at the Congress of the Latin American Studies Association, Rio de Janeiro, Brazil, June 11-14. 